\title{
BRANDING THE NATION: TOWARDS A BETTER UNDERSTANDING
}

\author{
Ying Fan \\ Brunel Business School \\ Brunel University \\ Uxbridge, London \\ UB8 3PH UK \\ Ying.fan@brunel.ac.uk
}

\begin{abstract}
This paper aims to clarify some misunderstanding about nation branding. It examines the origins and interpretations of the concept, and draws a comparison between nation branding and commercial branding. A new definition is offered that emphasises the need to shift from "branding" the nation to nation image management.
\end{abstract}

\section{Keywords}

Nation branding, place branding, nation image management, soft power 


\section{BRANDING THE NATION: TOWARDS A BETTER UNDERSTANDING}

\section{Introduction}

Nation branding is at cross-road. On the one hand the last 10 years have seen a huge growth in the interests and activities in the filed in form of publications, studies and consultancy projects. On the other hand, there is disappointingly lack of progress in conceptual development which is vital to move the subject forward (Fan, 2004, 2006; Dinnie 2007). As a result, nation branding still faces serious challenges from outright objection to cynical scepticism among the public (Olins, 2002; Kabn, 2006). A worrying development is that the subject has now been attacked from within: Nation branding does not exist, it is a dangerous myth. To branding a country is vain, naive and foolish, which creates the problem not the solution (Anholt, 2008). What is incredible is not the statement per se, but it was made by the right person who was widely credited with the creation of the term. To respond to the public scepticism on the use of the term branding, Anholt (2007) has recently re-brand the concept as "competitive identity", which is described as a new model for enhancing national competitiveness using both public diplomacy and brand management. However, he seems to be conflicting himself to claim on his website, that although the word "brand" is used, what he does (in nation branding) has nothing to do with marketing, advertising or public relations. The purpose of the short paper is to debunk the myth around the nation branding concept, by examining its origins and various interpretations, particularly on what is a nation brand, what is nation branding and what is not. Hopefully this would help to clarify misconceptions and point to directions for future research.

\section{The origins of nation branding}

Albeit being a relatively new subject, the origin of nation branding study can be traced to four different sources, namely, country of origin (COO) (Papadoplous and Heslop, 2002), place or destination branding (Kotler, et al, 1993; Kotler and Gertner, 2002; Morgan, et al, 2002), and more recently, public diplomacy (van Ham, 2001; Melissen, 2005; Fan, 2008a), and national identity (Smith, 1991; Bond, et al, 2001). Lee (2009) offers a good comprehensive review of the literature. Unlike the studies on $\mathrm{COO}$ and place branding which have a clear focus on promoting specific economic interests (export, tourism or inward investment), nation branding is concerned with a country's whole image on the international stage covering political, economic and cultural dimensions (Quelch and Jocz, 2004; Fan, 2006). 
As an emerging area of interest, nation branding is driven largely by practitioners and there is an urgent need for conceptual and theoretical development of the subject. In this regard, nation branding can benefit from the rich literature of organisation identity and organisation reputation (Hatch and Schultz, 1997, 2002 Stets and Burke, 2000). Compared with other three sources, national identity is a less visible but more promising one. The link between organisation identity and national identity with nation branding has yet to be fully understood.

\section{What is a nation brand?}

A brand, according to the classic definition by the American Marketing Association (1960), is a name, term, sign, symbol or design, or a combination of them which is intended to identify the goods or services of one seller or a group of sellers and to differentiate them from those of competitors. A brand is more than just a name; it is a complex bundle of images, meanings, associations and experiences in the mind of people. A more sophisticated definition is offered by Aaker (1996:68): a brand is a multidimensional assortment of functional, emotional, relational and strategic elements that collectively generate a unique set of associations in the public mind. Every country has a unique name and images in the mind of people both inside and outside the country, so a nation does have brands. A nation brand is the total sum of all perceptions of a nation in the mind of international stakeholders which may contain some of the following elements: people, place, culture/language, history, food, fashion, famous faces (celebrities), global brands etc. A nation's 'brand' exists, with or without any conscious efforts in nation branding, as each country has a current image to its international audience, be it strong or weak, clear or vague (Fan, 2006:12).

Two distinctions need to be made. Firstly a nation brand should not be confused with a national brand. In contrast with a global brand, a national brand is originated from a country, and its use is probably still confined to the country; while a global brand is recognised in the world marketplace. Secondly, when compared with a commercial brand, there are more differences than similarities. Unlike commercial brands, many elements in nation brand construct are not in the control of those engaged in nation branding management, they are difficult to change in the short term.

(insert Table 1 here) 


\section{What is nation branding?}

It is widely recognised that nation brands exist though opinions differ on what nation branding refers to, how a nation brand relates to nation branding and what nation branding should or could accomplish. The root of such confusion lies in the diverse interpretations of nation brands and branding (details are shown in Figure 1). There interpretations can be divided into six or seven levels. The simplest way is to treat a nation brand as a visual symbol, a slogan or strapline. As such, it can be easily branded and communicated. At Level B, a nation brand is regarded as an umbrella brand that endorses many sector brands, for example, in tourism or exports (Dinnie, 2007:200). A nation brand can also be treated as ingredient brand or co brand. At next level $\mathrm{C}$, a nation brand concerns the country's image, reputation and positioning, a role quite similar to that of corporate branding (Gilmore, 2002; Teslik, 2007; Roth and Diamantopoulos, 2009). At level D, nation branding aims to build and sustain a nation's competitiveness (Anholt, 2007; Lee, 2009; Porter, 1990). At Level E, nation branding helps enhance a country's soft power (Fan, 2007, 2008a; Nye 2004a, 2004b). At Level F, nation branding relates to national identity (Dinnie, 2007). This link may seem to be quite obvious but in fact the most complicated.

A close examination of some major definitions of the nation branding concept shows significant differences in the focus and purpose or outcome of branding the nation:

1. To remould national identities (Olins, 1999)

2. To enhance nation's competitiveness (Anholt, 2007; Lee, 2009)

3. To embrace political, cultural, business and sport activities" (Jaffe and Nebenzahl, 2001).

4. To promote economic and political interests at home and abroad (Rendon, 2003; Szondi, 2007)

5. To alter, improve or enhance a nation's image /reputation (Gudjosson, 2005; Fan, 2006, 2008b, 2009)

Identity, image and reputation, though often used interchangeably, the three terms are, in fact, different constructs. They all refer to mental associations generated by knowledge and past experience. Identity is about self perception. A nation's identity refers to the essentially irrational psychological bond that binds fellow nationals together and which is supposed to constitute the essence of national identity. Image is what is projected to other while reputation is the feedback received from other (Whetten and Mackey, 2002:400). Image and reputation, which is the reciprocal of image, both are components of a symmetrical communications process between the nation (self) and its international stakeholders (other). 
Thus, a nation's image is what a nation's people want the world to understand is most central, enduring and distinctive about their nation while reputation is a particular type of feedback received by the nation from the outside world, concerning the credibility of the nation's identity claims.

What nation branding concerns is the image and reputation a nation enjoys in the world. A nation's image is defined by the people outside the country; their perceptions are influenced by stereotyping, media coverage as well as personal experience. Like commercial brands, a nation's image can be repackaged, repositioned and communicated in a professional fashion. The relationship between national identity, nation branding and nation's image can be summarised as below:

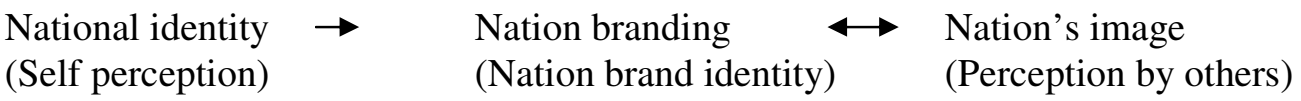

\section{What nation branding is not}

It is important to distinguish nation brand identity with national identity as these are two related but totally different constructs. Nation identity, to paraphrase Albert and Whetten's definition of organisational identity (1985), is the collective understanding by a nation's people of the features presumed to be central and relatively permanent, and that distinguish the nation from other nations. National identity embodies the characteristics of a nation that its people perceive to be central, distinctive, and enduring (CED) in a nation when past, present and future is taken into account. It refers to the essentially irrational psychological bond that binds fellow nationals together and which is supposed to constitute the essence of national identity. This psychological bond is usually termed "a sense of belonging" and such expressions point to the close link established between each individual and the collective self, namely the nation (Triandafyllidou, 1998).

National brand identity, on the other hand, refers to the identity of a specific "nation brand", not the nation. It is a set of associations the brand strategist seeks to create or maintain (Aaker and Joachimsthaler, 2002:43). More specifically, it can also refer to the visual symbol or logo that identifies the brand. As a country may have a number of different nation brands, it can have many different nation brand identities at the same time. 
Nation branding is not about "building or remoulding the national identity" as Olins (1999) initially suggested. A nation's identity is defined by the nation's people not by the branding strategist. Any change in a nation's identity is either accomplished or accompanied by fundamental changes in the country's political, economic and social systems. Instead, nation branding is about to alter the image that outside people hold about the nation. Nation branding in essence is to align the nation's image to the reality. This is particularly imperative for those countries that have undertaken dramatic changes in their political, economic and social systems, as the external images are almost always lag behind the reality. It is the task of nation branding to narrow the gap between the images and reality.

The role of nation branding in a nation's competitiveness is not as big as Anholt claimed in his new book (2007). In a commercial setting, a strong brand is said to bring its owner certain advantages over the competition. However, this kind of advantage depends on strength in other areas such as innovation, and is hard to sustain in the long term. It is a completely different situation in nation branding. If a nation have some advantages due to its favourable country image, this is normally confined to one specific industry sector, rather than covering the whole country. For example, fashion in Italy or engineering in Germany. The belief that nation branding creates the sustainable competitiveness for a nation may turn out to be a fallacy.

\section{From nation branding to nation image management}

Based on the above discussion, a new definition of nation branding is proposed as follows:

Nation branding is a process by which a nation's images can be created, monitored, evaluated and proactively managed in order to improve or enhance the country's reputation among a target international audience.

The use of nation image management is not just a change of terms but have a few benefits. It not only clarifies the confusion on what can be "branded" and what cannot be branded, but also helps overcome the public scientism over the use of branding. Nation image management describes more accurately about the topic subject as well as its chief objective in nation branding.

\section{Conclusions}

A nation brand is a complicated multi-facet construct that is dependent on the context such as other countries, special events or occasions. Even the critics of nation branding have admitted 
that nation brands exist. What they dispute is whether a nation can be branded. The answer depends on how one defines and interprets nation branding. Nation branding is an extremely difficult subject to research. All published empirical studies of "nation" branding, under close scrutiny, are merely export branding, or destination branding, with none of them actually branding at the nation level. For example, "Malaysia: Truly Asia" is just a tourism branding.

The biggest challenge in nation branding is how to communicate a single image or message to different audiences in different countries. The image of a nation is so complex and fluid as to deny the clarity implicit in a term such as brand image; and different parts of a nation's identity come into focus on the international stage at different times (O'Shaughenssy and O'Shaughenssy, 2000). In theory, nation branding calls for communicating in a coordinated and consistent fashion with multiple stakeholders. In reality, it is impossible to develop such a simple core message about a country that can be used by different industry sectors in different countries (Fan, 2006, 2007). One slogan, one campaign, no matter how clever or creative, can't sell everything to everyone. It would be more meaningful and practical to have nation branding to be conceptualised, measured and executed at one of sublevels (as a place brand, event brand or export brand).

Nation branding is not a myth. The impact of nation branding should not be exaggerated or dismissed. Socrates (469BC-399BC) once said: the way to gain a good reputation is to endeavour to be what you desire to appear. This remains true in the $21^{\text {st }}$ century. However, this is just one side of the coin. For a nation to change its image, it needs first to change its behaviour. Then, equally important, it needs to tell the people in the world about the changes. This is because images of a nation won't automatically change after the changes in reality. The way for a nation to gain a better reputation is to communicate to the international audience that how good you are, - this practice is called nation branding. 


\section{References}

Aaker, D. A. (1996) Building Strong Brands, Free Press, New York

Aaker, D. A. and Joachimsthaler, E. (2002) Brand Leadership. Free Press Business, Sydney. Albert, S. and Whetten, D. A. (1985), Organisation identity, in Cummings L. L. and Staw, B. M. (eds). Research in Organisational behaviour, Vol 7, 263-269, JAI Press, Greenwich, CT Anholt, S. (1998), "Nation-brands of the twenty-first century", Journal of Brand Management, 5:6, 395-406

Anholt, S. (2007) Competitive identity: The new brand management for nations, cities and regions, Palgrave Macmillan, Basingstoke

Anholt, S. (2008), "Why nation branding does not exist?" available at http://www.orangecontest.nl/docs/SimonAnholtNationBranding.pdf

Bond, R., McCrone, D., and Brown, A. (2003) "National identity and economic development: reiteration, recapture, reinterpretation and reputation", Nations and Nationalism, 9, 371-391.

Dinnie, K. (2007), Nation branding: concepts, issues, practice, Butterworth Heinemann

Fan, Y. (2004), "Nation branding: Confusion and paradox", 33rd EMAC Conference, Murcia Fan, Y. (2005), "Can a nation be marketed like products?" PKU Business Review, No.9, in Chinese

Fan, Y. (2006), "Banding the nation: what is being branded?" Journal of Vacation Marketing, $12: 1,5-14$

Fan, Y. (2007), "Soft power and nation branding", Brunel Business School Research Papers, http://bura.brunel.ac.uk/bitstream/2438/1863/4/Soft\%2BPower\%2BCh.pdf

Fan, Y. (2008a), "Soft power: the power of attraction or confusion", Place Branding and Public Diplomacy, 4:2, 147-158

Fan, Y. (2008b), "Self perception and significant others: A conceptual framework for nation image", The Sixth Conference of Asia Academy of Management, Taipei, Dec. 14-16

Fan, Y. (2009) "A conceptual model for nation image and its implications for future research", forthcoming

Gilmore, F. (2002) "A country -can it be repositioned? Spain -the successful story of country branding", Journal of Brand Management, 9:4/5, 281-293

Gudjonsson, H. (2005) "Nation branding", Place Branding, 1:3, 283-298

Hatch, M. J. and Schultz, M. (1997), "Relations between organisational culture, identity and image", European Journal of Marketing, 31, 356-365

Hatch, M. J. and Schultz, M. (2002), "Scaling the tower of Babel: relational differences between identity, image, and culture in organisations", in Schultz, M,

Jaffe, E. d. and Nebenzahl, I. D. (2001), National image and Competitive Advantage The theory and practice of country-of-origin effect. Copenhagen Business School Press

Kabn, J. (2006) “A brand-new approach”, Foreign Policy, Nov./Dec. available at http://www.foreignpolicy.com/story/cms.php?story_id=3608

Kotler, P., Haider, D. H. and Rein, I. J. (1993) Marketing Places: attracting investment, industry, and tourism to cities, states and nations, Free Press, NY

Kotler, P. and Gertner, D. (2002), "Country as brand, product, and beyond: a place marketing and brand management perspective", Journal of Brand Management, 9:4/5, 249-261

Lee, KM, (2009) "Nation branding and sustainable competitiveness of nations", $\mathrm{PhD}$ thesis, University of Twente, available at http://doc.utwente.nl/60754/1/thesis_K_M_Lee.pdf. Melissen, J. (2005) Wielding soft power, the new public diplomacy, Clingendael Diplomacy Papers, No.2, Netherlands Institute of International Relations Clingendael

Mselle, F. (2007), "A critical analysis of the current state of knowledge of nation branding", MSc Thesis, Cranfield School of Management, available at https://dspace.lib.cranfield.ac.uk/handle/1826/2699 
O'Shaughenssy, J. and O'Shaughenssy, N. J. (2000), “Testing the nation as a brand: some neglected issues", Journal of Macromarketing, 20:1, 56-64

Olins, W. (1999), Corporate identity: Making business strategy visible through design, Harvard Business School Press, Boston

Olins W. (2002), "Branding the nation - the historical context", Journal of Brand Management, 9:4-5, 241-248

Nye, J. S. (2004a) Soft Power: the means to success in world politics, p7-8, Public Affairs, NY

Nye, J. S. (2004b) “The decline of America's soft power”, Foreign Affairs, May/June

O'Shaughenssy, J. and O'Shaughenssy, N. J. (2000), "Testing the nation as a brand: some neglected issues", Journal of Macromarketing, 20:1, 56-64

Papadopoulos, N. and Heslop L. (2002), "Country equity and country branding: problems and prospects", Journal of Brand Management, 9:4-5 294-314

Porter, M. (1990) The competitive advantage of nations. Free Press, NY

Quelch, J. and Jocz, K. (2004), "Positioning the nation-state", Place Branding, 1:1, 74-79

Rendon, Jim (2003), "When nations need a little marketing." New York Times, November 23.

Roth, K. P. and Diamantopoulos, A. (2009) "Advancing the country image construct", Journal of Business Research, 62, 726-740

Skinner, H. and Kubacki, K. (2007), "Unravelling the complex relationship between nationhood, national and cultural identity, and place branding”, Place Branding and Public Diplomacy, 3:4, 305-316

Smith, A. D., (1991) National Identity. Penguin Books, London

Stets, J. E. and Burke, P. J. (2000) "Identity theory and social identity theory", Social Psychology Quarterly, 63:3, 224-337

Szondi, G. (2007) 'The Role and Challenges of Country Branding in Transition Countries: the Central and Eastern Europe experience' Place Branding and Public Diplomacy 3(1): 8-20. Teslik, L. H. (2007) "Nation branding explained", Council on Foreign Relations http://www.cfr.org/publication/14776/nation_branding_explained.html Triandafyllidou, A. (1998), National identity and the "other", Ethnic and Racial Studies, 21:4, 593-612

Van Ham, P. (2001) The Rise of the Brand State: the postmodern politics of image and reputation", Foreign Affairs, October 10.

Whetten, D. A. and Mackey, A. (2002), "A social actor conception of organisational identity and its implications for the study of organisational reputation", Business \& Society, 41:4, 393-414 
Table 1. Comparison between nation branding and commercial branding

\begin{tabular}{|l|l|l|l|}
\hline & Nation brand & Product brand & Corporate brand \\
\hline Offer & Nothing on offer & $\begin{array}{l}\text { A product or service on } \\
\text { offer }\end{array}$ & $\begin{array}{l}\text { Related to the product or } \\
\text { sector }\end{array}$ \\
\hline Attributes & $\begin{array}{l}\text { Too complicated to } \\
\text { define in simple terms }\end{array}$ & clearly defined & Well defined \\
\hline Benefits & Purely emotional & Functional and emotional & Mainly emotional \\
\hline Image & $\begin{array}{l}\text { Complicated, diverse, } \\
\text { vague }\end{array}$ & Simple, clear & Simple, visible or hidden \\
\hline Association & $\begin{array}{l}\text { Secondary, numerous } \\
\text { and diverse }\end{array}$ & $\begin{array}{l}\text { Primary and secondary, } \\
\text { relatively fewer and more } \\
\text { specific }\end{array}$ & $\begin{array}{l}\text { Mainly secondary, } \\
\text { fewer and specific }\end{array}$ \\
\hline Purpose & $\begin{array}{l}\text { To enhance national } \\
\text { reputation }\end{array}$ & $\begin{array}{l}\text { To help sales and develop } \\
\text { relationships }\end{array}$ & $\begin{array}{l}\text { To enhance reputation and } \\
\text { develop relationships }\end{array}$ \\
\hline Dimension & $\begin{array}{l}\text { Political, economic, } \\
\text { social and cultural }\end{array}$ & Mainly economic & Economic and social \\
\hline Ownership & $\begin{array}{l}\text { Multiple stakeholders } \\
\text { Unclear }\end{array}$ & Sole owner & Sole owner \\
\hline Audience & $\begin{array}{l}\text { International, diverse, } \\
\text { "significant others" }\end{array}$ & Targeted segment & General public or targeted \\
\hline
\end{tabular}

Source: adapted from Fan (2006:7) 
Figure 1 The Concept of Nation Branding: Origins and Interpretations

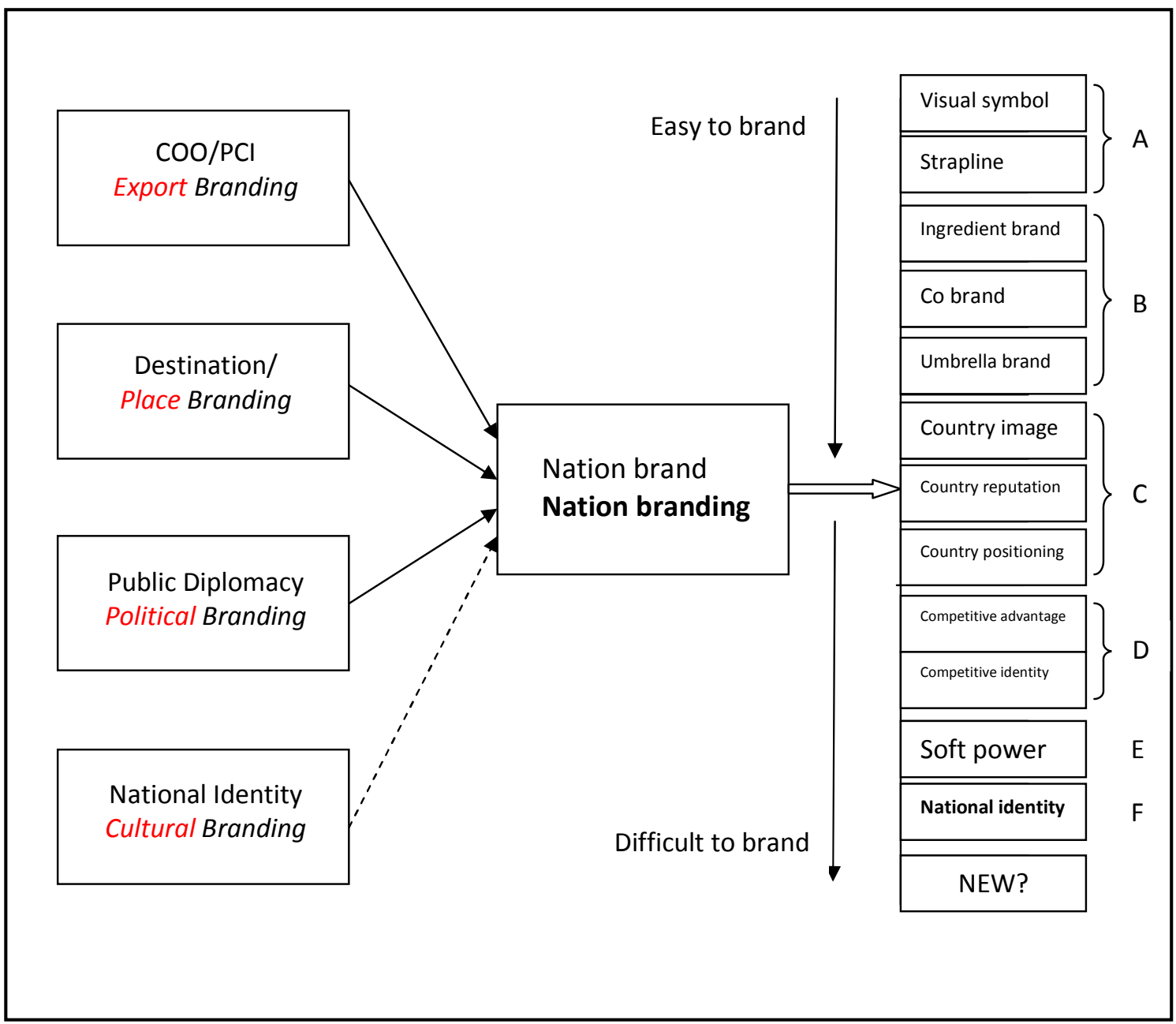

Source: by the author 